\title{
REFLECTIONS ON THE ROLE OF MANAGEMENT IN ACHIEVING A SUSTAINABLE FUTURE: \\ AN INTERVIEW WITH TIM FLANNERY AND DEXTER DUNPHY
}

\author{
Sally V. Russell \\ Asia-Pacific Centre for Sustainable Enterprise \\ Griffith Business School \\ Griffith University
}

\section{PREPUBLICATION VERSION}

Please cite as:

Russell, S.V. (2010). Reflections on the role of management in achieving a sustainable future: An interview with Tim Flannery and Dexter Dunphy. Journal of Management \& Organization, 16 (1): 1-15. 


\begin{abstract}
This article reports an interview with Professors Tim Flannery and Dexter Dunphy conducted during the Australian-New Zealand Academy of Management (ANZAM) Conference in December 2009. Flannery and Dunphy share their thoughts about the meaning of sustainability and what is required of business, government and individuals in responding to global environmental problems. Both professors express their passion for sustainability and clearly articulate the vital role that business and management play in achieving a sustainable future. The interview is followed by a discussion of the major themes and implications for management educators, researchers and practitioners.
\end{abstract}

Key words: sustainability, natural environment, corporate responsibility, climate change 
Managers are becoming increasingly aware of the need for their organizations to operate more sustainably. Words and phrases such as sustainability, climate change, and greening have become part of our everyday business lexicon. But words are not enough; researchers argue that organizations have played a large part in creating current environmental issues, and they must therefore play a role in responding (Dunphy, Griffiths, \& Benn, 2007; Shrivastava, 1995; Starik \& Marcus, 2000).

In December 2009, the Australian-New Zealand Academy of Management hosted its $23^{\text {rd }}$ annual Conference. The theme of the conference was 'Sustainable Management and Marketing' and the two distinguished keynote speakers were Professors Tim Flannery and Dexter Dunphy. Their keynote presentations discussed how management practitioners and academics could take up the significant challenge of achieving sustainability and redressing global environmental problems.

Professor Tim Flannery is an internationally acclaimed writer, scientist and explorer who was named Australian of the Year 2007 in recognition of his contribution to the environment and other fields. Professor Flannery holds a PhD in paleontology from the University of New South Wales and is currently a professor at Macquarie University. He has published more than 130 scientific papers and has written many books, including his recent bestseller The Weather Makers: The History and Future Impact of Climate Change (Flannery, 2005). He is the chairman of the Copenhagen Climate Council, an international climate change awareness group, chairman of the South Australian Premier's Science Council and Sustainability Roundtable, a director of the Australian Wildlife Conservancy, and the National Geographic Society’s representative in Australasia. He is also an active member of 
the Wentworth Group of Concerned Scientists, which reports independently to government on environmental issues of concern to Australians.

Professor Dexter Dunphy is an Emeritus Professor in Business at the University of Technology Sydney. He holds a PhD in Sociology from Harvard University and has held teaching positions at Harvard, the University of New South Wales, and University of Technology Sydney. Professor Dunphy has consulted to over 160 private and public sector organizations in Australia and abroad. His main research and consulting interests are in corporate sustainability, the management of organizational change and human resource management. His research is published in over 90 articles and 24 books. He has received numerous commendations, including the Fulbright Senior Scholar Award and the University of New South Wales’ ViceChancellor's Award for Teaching Excellence. In 2007 he was appointed a Member of the Order of Australia for service to education, particularly in the fields of organizational change, corporate sustainability and business management, and to the community.

I was invited by the ANZAM executive to interview Professors Flannery and Dunphy because of my research and teaching interests in sustainability and organizations and the natural environment. I spoke with Flannery and Dunphy and explored their perspectives on the contribution that business, and management in particular, can make in addressing climate change and achieving a sustainable future. The edited transcript of this interview appears below. Primary sources are cited where relevant in order to assist readers. 
Given that the theme of this year's ANZAM Conference is sustainability, what does that really mean to you? How do you talk about sustainability or what sort of images do you have in your mind when you think about what sustainability means?

Flannery. Well I've thought a lot about sustainability over the last three years because I'm writing a book about sustainability. Ultimately what it means for me - I just have two words - “intelligent earth”. It's the creation of an intelligent earth. The Gaian system that Lovelock (1979) described is very real and everything is interconnected but it works through what I'd call geo-pheromones. Just as an ant colony works through pheromones; we get this seamless integration of millions of ants communicating through just 30 or 40 basic pheromones. Well, the earth system works sort of the same way. So it's not a very competent system. It doesn't have a command and control element to it. It can't actually deal with threats before they arise. But humans are now poised to become the command and control system for the planet. The creation of intelligent earth through that process is what I see as sustainability.

Dunphy. I'd relate that back to what the great Jesuit philosopher, Teilhard de Chardin, talked about: the noösphere ${ }^{1}$ which was, as he saw it, the Earth gaining intelligence about its life. So this is another approach to the Gaia system. The Earth has become self-conscious through humanity. The only problem is that it's a bit like the relationship between the ego and the id in Freudian terms. In modern society there seems to be a disconnect between the Earth's body, the fundamental consciousness of the Earth, and the intellect, the human understanding of the Earth. Indigenous people around the world had a deep connection with the land and

\footnotetext{
${ }^{1}$ The noösphere can be described as an unfolding of individual and collective consciousness. It is intrinsically linked to the notion of evolution of planet Earth, where evolution is conceptualized as consisting of three phases: the physical formation of the planet (the geosphere), the birth of life (the biosphere) and the emergence of human consciousness (the noösphere) (Samson \& Pitt, 1999).
} 
understood themselves as part of nature with a responsibility of guardians to that nature. If you look at [Australian] Aboriginal life, everything rotated around renewing the Earth. I think the greatest task for us is to find, as inhabitants of the earth, a similar kind of relationship and understanding. An understanding that we're not the masters of the Earth; we are part of the guardianship of its life.

We don't have the 40,000 years that the Aborigines took to reach that level of understanding. They developed an understanding that the Australian continent was very fragile and they had an important part in renewing its life and that's what their life centered around. That was their sacred duty. We can't go back to their understanding but we have to develop similar understanding; we may have at the most 40 years to develop that.

Flannery. It's interesting you mention the disconnect between the body and the brain because in some ways that's true of our own bodies. If you look at the way the brain works in our own body you see that it is an incredibly selfish organ. It weighs only two per cent of our body mass but uses 20 per cent of our energy, and it will close down any other organ before it lets itself suffer any shortfall, and yet we still function as a body. I think it's the nature of intelligence to be selfish and greedy but it doesn't mean it has to be destructive.

The other thing about the brain of course is it's really an illusion. There are two hemispheres which are rather poorly connected. There's the basal brain and then the middle mammalian brain, and we all experience in our lives how one of those brain elements can take over. When we get a fright one takes over; when we're very emotionally charged one element takes over. Yet generally we function as a competent entity, so human intelligence of the earth is going to be no different from that. It's going to be the same sort of thing; we won't have a controlled world 
government like an ant colony, we'll have these disparate elements that work in harmony, not entirely in harmony, but generally in harmony. If intelligent earth is realized we'll still be selfish and greedy but we just won’t bankrupt the system.

Dunphy. I think we also inherit two philosophical traditions which are not helping us. One is the Newtonian understanding. We think of the earth as a machine, not as an organism, and so we have to relearn that it is an organism, not a machine. But we still have the machine analogy and Western management in particular works on a machine model still, quite unconsciously.

The second thing is the Darwinian model. I'm an admirer of Darwin but it seems to me that Darwinian philosophy understood the competition but failed to see the synergies that maintain that competition. So I see the social world, and the economic world, as like a coral reef in which there's intense competition within niches within a coral reef but also incredible synergies which maintain those niches. Modern economists, drawing from Darwinian Theory, overlook the synergies and exaggerate the competition. The competition is actually vital for survival but so are the synergies. So we have to learn to understand the synergy and translate that into restoring the loss of infrastructure that's taken place in most Western economies as a result of neo-liberalism. We have to rebuild the economic and social infrastructure that we have destroyed in the last 20 to 30 years.

Flannery. That's true. The way I tend to see it is that competition is the driver of evolution but the legacy of evolution is cooperation; and the legacy of anything often lasts far longer than the driving force. The driving force will pass away but the legacy will still be there. So we live in an inherently cooperative world. Competition is the driver of evolution but cooperation is its legacy. 
This is self-evident in everything. For example, the business suits that we wear, when business is all about competition but actually it isn't. Why do you wear a suit? You wear a suit to mask your own individuality because it’s incredibly important in a board meeting that people work together as a team. So you have to wear on your body the physical evidence, your bona fide is that you will work together as part of a team. You can hide your little bit of individuality in there, a little flash of blue or purple or whatever you want, but you've got to be part of the team. Even the world of intense competition recognizes that the legacy is actually cooperation. What we see in nature we also see in our society, unsurprisingly in our businesses, and in everything else.

\section{So taking that point up, what role do you see businesses playing in achieving sustainability and addressing climate change?}

Dunphy. I sit on the Westpac's Community Consultative Council which meets with the Chief Executive and it consists of about 20 people, mainly heads of not-for-profits. All that happens is the Chief Executive sits down and says, "All right, I'm interested in what you're thinking about. If you think of the next five to 10 years, what are the issues that are on your mind?” So there’s one company, for example, which is I think doing something highly intelligent from a business point of view but is also community-minded. This is a good early warning system from a simple business perspective to ask "What's going on out there in the community?"

I’ve been on that Council for several years and I looked through my notes to see to what extent this company had taken into account the issues raised. I couldn't find a single significant issue that hadn’t been taken up, fed into their strategic planning department and turned into a policy and a set of procedures. I thought that was pretty impressive and as a result they have achieved global leadership in the 
banking industry. The interesting thing is they keep saying “we do this because it’s good citizenship. The reality is, as it turns out looking backwards, we made money but that's not why we did it.”

But on the other side, I'm very critical of the Rudd Government. I don't believe when Rudd came into power with the rhetoric of saving the world that the carbon and mineral lobby even blinked. They simply moved in and took over and they're the most powerful lobby in Australia. They look after their own interests, none other. I don't believe they have the national interest at heart.

I think Rudd had an opportunity to put it on the line and to say a very difficult political thing. When he first came in he could have said "we are going to phase out coal-fired power stations, we're going to do it over 10, 20 or 30 years and this is how we're going to do it." He lost that opportunity; and he failed to sell this new legislation, now before parliament, to the community. Even Howard did a better job.

I'm not optimistic about the usefulness of this legislation. I think in many ways it's been a distraction from the main game. Well, I guess that's where I am on that one.

Flannery. In terms of business; business, by and large, has to do, they have to deliver on these things. Government won't be building the new power plants or the new solar panels, business will be doing that. But if they're to do that, business needs to have a regulatory environment that allows them to do that and make a profit at the same time. That's what the role of government really is, to create that regulatory environment that allows business to go ahead and make a profit.

That's why in part the CPRS [Carbon Pollution Reduction Scheme] is so important - it sends a signal to business. Sure, the costs are going to be paid by you and me as tax payers in the medium or short term. But if you take a 10 or 15 year time 
frame and look at the major energy companies and the sort of investment decisions they're making in terms of new energy infrastructure, it's really important that the Government creates a new regulatory environment where they invest in more expensive yet more sustainable infrastructure. So that's the way I see that.

Dunphy. I agree with that. But if we look at what governments are actually doing: recently, the New South Wales Government announced that it was going to build two new gas- or coal-fired power stations which will have emissions equivalent to all the cars in New South Wales for coal, or half that for gas. So we're still going down the path of increasing emissions despite the rhetoric.

What we have is those polluting companies, and many of them I might say have very good track records in other areas. For example, they have introduced very positive things under the banner of sustainability like effective policies for indigenous employment. Many also have really good positive records in land reclamation. However, the most critical thing that happens in industry is what the business of the industry is, which is to make a profit and, in this case, to run a mine or run a coal station or pull coal out of the ground. The very people who will talk about free enterprise most rhetorically, are the ones who are actually not working on a level playing field but who are massively subsidized historically. In some cases I think we've actually paid these companies to take our coal out of the ground and sell it overseas. Most of these companies are not Australian-owned and much of the profit is repatriated overseas so we don’t get the benefit of that and they have very interesting ways of not paying their dues here and repatriating more profit overseas.

So in that sense they're not good corporate citizens and they cry poor. They cry that jobs are going to be reduced. They're the ones who reduce them. If you take the mining industry, for example, who has reduced the jobs in the mining industry? 
It's the mining industry companies themselves that have reduced jobs by introducing new technologies. Or take forestry - who's reduced the jobs in forestry? The forestry industry has reduced the jobs in forestry and wiped out the local employment and so on and so forth.

I can’t feel very sympathetic for them, nor can I feel very sympathetic for them on the possibility that their profitability might be reduced by introducing effective environmental measures - although there's no sign of that whatsoever. Because they're heavily subsidized, that goes against the development of new alternate energies which we desperately need to have developed.

The largest contributor to the economy is in fact the service sector. We have no effective service sector lobby in Australia and the mining industry dominates the Business Council of Australia [BCA]. A few years ago, we had Westpac and BP, and others, stand up and try to move the BCA to publicly recognize that climate change was occurring. The BCA's official position on climate change was to deny it was happening. This lobby group managed to change the BCA's position to a neutral one, saying it may or may not be happening, that's as far as they could get the BCA to move. But that lobby was then effectively shut up by the miners.

Flannery. I don't disagree with you about any of that but I've got a motto in my mind; I just say never get angry, just get even.

Dunphy. Well, I'm angry at this point. Evil has never been word that I've used but I'm beginning to use it now because we are faced with the demise of a habitable world for our children and our grandchildren. And we have people who know, who are informed, and who are locking us into the industries of the past. Even from a business point of view, from an Australian economic point of view, this is destroying our economic future. I get angry, I’m sorry. 
Flannery. I can't allow myself the luxury of getting angry, it burns up too much energy.

I'd like to follow up on the emotion you are speaking about. Faced with such huge challenges and all of the issues that we have to face, how do you maintain hope? It's something I've been in interested in as an emotions researcher ${ }^{2}$ and I see how without hope we can move into despair which doesn't lead to action. So how do you maintain hope faced with such daunting challenges?

Flannery. Well, I don't think you need to maintain hope to remain active. Winston Churchill is probably the great example of that in 1941. We've just got to keep going. Sometimes you've just got to keep going, and this is one of those times where you've got to keep going. So that's how I deal with it. I don't even allow myself to ask the question of whether we're going to make it or not. Just keep going and do the best you can to make sure you do that. So that's my method of coping with it all.

I don’t ever go into despair; I’m grateful for every day to be there, but just to make sure that you just deal with it with absolute determination every day. If you get angry, just get even. Never get despairing, just keep pushing on.

Dunphy. I love the natural environment. And I have some land up in the bush where I love to spend time; it does nothing for the future for me to be consumed by despair at what is happening and so destroy my day-to-day enjoyment of the beautiful and mysterious world that I've been bequeathed. My father and my brother [Myles and Milo Dunphy] were great environmentalists when that wasn't an 'in thing' to be. Their work is going to be destroyed by climate warming. All of the National Parks in New South Wales which they gained are going to be destroyed if we continue down this path. But despite these issues I believe that it's possible to live in and continue to

\footnotetext{
${ }^{2}$ See Russell (2009)
} 
enjoy what we have while we have it; to do what we can to maintain it for our

children and our grandchildren and everyone else's as well.

You've both given examples of businesses that are doing just that. I notice that Shai Agassi [CEO and founder of global electric vehicle provider, Better Place] is on the Copenhagen Climate Council; and you've given examples of Fuji-Xerox and Westpac. They're really positive examples of alternative approaches to business or how new technologies can be adopted. How do we learn from those organizations in order to change the businesses-as-usual approach that we see in mining companies and other organizations that aren't taking on those new approaches to doing business?

Dunphy. I do see some hope in what I'm seeing happen now, because I was working with the financial arm of one of Australia’s major insurance companies. They finance large city buildings and retail centers. In working with them, I have been asking questions like: "Why not invest the funds that have been entrusted to you only in six-star energy-rated buildings? Otherwise you may have to retrofit the buildings in five years time and that's going to cost your investors money?” They've bought that argument so they're looking carefully now at the environmental and social attributes of the buildings that they put investors' money into. I've worked with Lend Lease where all their buildings have to meet high environmental ratings and they're trying to get all their clients' buildings up to that level. Then there are a range of other companies which are now working back through their supply chains to try to make them sustainable throughout. What I'm seeing is those efforts across different industries coming together now and starting to mutually reinforce each other.

They're all aware of each other's work, they tend to use each other as collaborators in business ventures and we're now beginning to see the impact of, not one, but many leading edge companies starting to set the pace for their industries.

That is new and it is backed by the development of the internet and the accessibility of knowledge about what is the leading edge practice now. 


\section{We go back to the point of cooperation that you were both talking about earlier.}

Flannery. That's right, it's exactly that level of cooperation that's needed and companies that don't do that will be disadvantaged. I think that one thing with these companies, that the mining companies and others who ignore the issue don't see, is that there is no way you can't expend capital on this. You either expend real capital on it or you expend your social capital on it.

So far some companies have been happy to make record profits and expend their social capital as if it doesn’t matter. But that gets you to a certain point where it's very, very dangerous and I think we are approaching that point. That's one of the things that I've been focusing on. [These companies] have no respect in the general community. You go so far down that you lose your social license to operate. Bright young graduates won’t go to these companies. The bright young kids want to go and work for the companies with a future.

The world is changing so quickly that this trend will only accelerate. For example, WWF and Google are now putting together a map of global environmental pollution sites. You or I could go out to the local tip and take a picture and it will just go on Google Earth, and that'll all be tied to individual polluters and so forth. Can you imagine what that means over the years? Maybe two years from now we'll be able to look at the top 10 spots tied to the company doing it and see the physical damage. This is our intelligent earth taking shape.

Not only that, there's voting platforms that now exist where people might ask the question, “Do you believe this company should face fines of X?” And you'll have a vote. A very significant portion of people will be able to vote and there'll be 
parallel voting systems. The Vote $\operatorname{Earth}^{3}$ campaign is just the first of these. It's one vote per IP address.

I think in five years time we'll have a parallel election system in Australia. We'll have not only a Federal Election but a parallel virtual online election with key issues. Of course, if you get a significant number of Australians doing that, the outcome is of that parallel election system will simply not be able to be ignored. So we will start seeing real change at that point. It's going to take some time but we've got the tools now where we can coherently act to send a single strong message as a species. That hasn't really existed before. So I think we're at a point of great transition at the moment and part of the most important thing we can do is hasten that transition.

\section{So what you're saying is that it's really consumer driven. Is that right?}

Flannery. Well, you don't have to be a consumer; you just have to be a person. Because what these companies are doing, the ones that are socially bankrupting themselves, is that they're profiting at the expense of you and I. They've been able to do that in the past because you and I haven’t had a voice. So great social reforms of the $19^{\text {th }}$ Century were a bit the same; people didn't have a voice, they didn’t have a vote.

That changed in the $19^{\text {th }}$ Century and we got social reform. The $20^{\text {th }}$ Century was all about war and peace. This Century is going to be about environmental reform and it will be empowering individuals where profits are being made at their expense. That's the sort of paradigm that we're moving towards.

Dunphy. I think probably the next revolution will be the consumer revolution. I agree with what you're saying. I think there will be a consumer revolution but it

\footnotetext{
${ }^{3}$ Vote Earth is part of WWF's Earth Hour campaign, which aims to raise awareness of climate change and encourage sustainability (WWF, 2010).
} 
isn't really under way yet. There are a number of things coming together; it's not just global warming. Peak oil, for example, is going to have a huge effect because as the Indian and Chinese economies drag in more and more oil, then oil production is not going to match demand. There will be increasing discrepancies between the production and demand and that will create a situation where the price of oil goes up dramatically. That's going to drive us back to the localization of production.

For example, one of Australia's major food retailers is substantially reducing the number of their distribution centers in Australia, where all the fresh produce and other goods goes in and gets stored. Now just think what that means in terms of oil use. First, oil is used in growing the food, harvesting it, transporting it to these centers. Power is used - these cool rooms are the size of city buildings lying on their side. Then all the food goes into 13 points around Australia, it comes out from there more oil is used in the distribution of that food around Australia; and sometimes food is transported back to where it was grown. This is madness.

As the price of oil rises, that will be a disastrous business strategy. So we're going to be forced back to distributed local production of most things, from electricity to food. That is going to be much more efficient than the centralized systems, the big centralized systems, and safer.

Flannery. The same is true for energy. You see distributed power becoming so important in your local photovoltaics - in New South Wales now you can buy two kilowatts of solar panels for $\$ 2,999$.

Dunphy. I paid \$18,000 for mine years ago.

Flannery. I paid $\$ 9,000$ for mine a year ago. So the price is just coming down like you wouldn't believe. The payback time for those panels now is two years. Distributed power is here, we're on the brink of it. Once we get electric vehicles 
we'll have storage capacity for that intermittent source of supply. It's the democratization of energy. What Dexter has been talking about is democratization of food and everything else. It will happen and it'll be part of this big push that's just taking shape now.

What role do you think business schools and universities more generally play in starting to take on and teach these new models of doing business? Because at the moment I think we're very much stuck in teaching the old model for business.

Flannery. Forgive me for being blunt, but universities are in the position of teaching young people, “do as I say, not do as I do.” The models the universities are run by are unsustainable in their own right. I would love to see a vice chancellor step up and change that. They'd say we're actually going to restructure this university to be a $21^{\text {st }}$ Century university, to be doing as we do and as we say.

That would mean changing its energy generation, the way it gets its students to and from its classes or really even if they're more virtual classes. It would mean driving accountability right through the university. Accountability is such a major issue and people don’t seem to take it all seriously. Someone needs to lead and someone needs to see it as a social environment.

We need to change and say, okay, here's the new model, here's what we're going to do. It'll take a decade but this is where we want to be at the end of the day. You need a VC to take this on as a core commitment. It's not just optional but it is the core business of the university. At the moment VCs want to build more buildings and have the greater glory, but there isn’t one out there who actually sees this as absolutely core. But we need one who will spend a decade of hard work to do it. 
Dunphy. So it's two things: it's modeling in the way the university is run, what it should be teaching, but it's also revising the curriculum to make this central in the curriculum right across the university.

Flannery. That's right, it's all of that, and it's everything from management and infrastructure through to curriculum and the whole thing. Someone needs to actually take a hold of that and say that we're going to design a university that's fit for purpose in the $21^{\text {st }}$ Century, in my view. "Do as I say and not do as I do" is not good enough anymore. We've actually got to do it.

\section{How do you convince people when you're faced with those that don't believe in climate change or don't agree with the science? How do you combat that or what do you do to convince people?}

Flannery. Well, it depends on who and where. If there's someone who's just a dyed-in-the-wool skeptic and genuinely doesn’t want to know, I just don’t bother; it's a waste of time. But if there is someone who is uncertain about it, I try to get to the base of why they're uncertain in what they've heard and then try to recommend some material that they might read or which will inform them a bit better.

Sometimes it’s An Inconvenient Truth (Gore, 2006), sometimes it’s something else. But I think you can try to engage with their specific problem because it's not like there's a one size fits all for climate skeptics. It ranges from the cynical and Machiavellian through to the genuinely ignorant. You've just got to work through it.

With farmers, who are a group I’ve done a lot of work with, and they say "no climate change here, mate, we haven’t noticed any change.” Normally I get a room of 500 and say, “Okay, you guys, can you think back to the 1950s, I don’t know what you were doing back then but probably if you had a shave in the morning you'd have a mug beside your bed with some water in it and you could have a shave in the 
morning, or you might have had a horse trough. Do you remember how it used to skin over with ice?”

“Oh, blood oath, I used to get three quarters of a bloody inch of ice on my shaving mug when I was a shearer.”

I’d say, "When was the last time you saw anything like that? Don’t know, when was it?” I say, "Well, the reason that we don’t have ice forming on water bodies in Australia now is that all of the heat's being kept in overnight. So there's a lot of variability during the day because the sun is out there and it can be cloudy or whatever but overnight is when you really notice the difference. ${ }^{4}$ So your own life has got a living testimony to this shifting climate.” They go, “oh yeah”, and the light goes on a bit.

So you've got to pick an example that's relevant to people - that they have observed. That's the genius of An Inconvenient Truth (Gore, 2006). It took concerns and feelings we all had and produced a framework to allow us to make sense of them. I think if we do that with people it's very powerful.

Dunphy. There are other skeptics, who say, “Look, even if you are right about global warming happening, it’s not caused by us.” So I say, “Even if you are right, the kinds of things that are being advocated in terms of changes in society, for example changes in our generation of electricity, are more efficient; it is actually more efficient for example to produce electricity now by alternate means than by coal-fired power plants.” Eighty per cent of the heat produced by power plants is lost either in the process of generation of electricity or in the transmission. It's much more efficient to produce electricity locally using alternate technologies. The solar panels

\footnotetext{
${ }^{4}$ Records show that average temperatures in Australia have risen by $0.7^{\circ} \mathrm{C}$ over the past century, with more frequent very hot days, and less frequent frosts and very cold days (Collins, Della-Marta, Plummer, \& Trewin, 2000; Plummer, et al., 1999). Evidence also shows that night-time temperatures have risen faster than daytime temperatures (Pittock, 2003: 47); see also Flannery (2005: 140).
} 
on my roof for example; if I turn on the electricity in my house for lights or something, electricity comes straight down, no loss. If my excess electricity is pumped into the grid, and if there's a shop up the street with a freezer then it goes up to the shop. So there's essentially no transmission loss. So what we're looking at is a transition to a no carbon society which will be a lot more efficient in producing and maintaining our standard of living than what we currently have which is extremely wasteful. So why wouldn't we do it anyway?

Flannery. Yes, and no regrets, exactly. The other argument I use with business particularly, is an insurance argument. I just say, let’s assume that you might be right but there's a small chance that you're wrong and climate change really exists. The worst case scenario, if we follow your path, is destruction of the planet. The worst case scenario if I'm wrong is that we spend a bit of money. So it's just like paying insurance. No one can predict the future; we can only work on the basis of probabilities.

Dunphy. Well, if you talk with insurance companies, they're terrified, for a good reason. They've charted the trends in weather events and become big advocates of taking action on climate change.

\section{Is there any more you have to say about management as a discipline and what its contribution could be?}

Flannery. I just think that what Sir Richard Branson said to me opened my eyes. He just said, “A lot of business people I know think that if they look after their employees and make a profit they're running a good business.” He said, "Well, actually that describes a criminal syndicate; but not a modern business.” Ethics has to be the basis of any modern business because business is so powerful they can drive us 
into societal bankruptcy or environmental bankruptcy very quickly. So we need to be harnessed to the social good. I just thought that was such a logical way of saying it.

Dunphy. I think there's not enough attention paid to the core business. A lot of businesses say they're sustainable because they're helping people by doing paternalistic kinds of things; but for me I'm looking at the core of the business, and saying what do you do? So if you're a Gunns ${ }^{5}$ and you're ripping out Australia’s precious environment, I don't care what you do in the way of giving some money away to a charity or something or other, I'm concerned about the core business you're in. That's the test. And some businesses need to go out of business.

Flannery. Another example is coking coal ${ }^{6}$, Anglo Australian coal miners, big coking coal people, and massive problems with the environment. If they saw themselves as a producer of reductant for steel making, rather than as a coal miner, they would be a totally different business. We know the best reductant by any standard for all steel making is charcoal. If they made pelletized hybrids of perhaps some coal initially and some charcoal that is tailor made for each furnace around Australia, they'd be making a fortune. It makes me so angry because they can't see their own business by what's happening. What they do instead is decide to be the least-cost producer of coking coal. That's such a bankrupt business model. They need to change their model. So that's the mindset that has to shift.

\footnotetext{
${ }^{5}$ Gunns Ltd. is a large timber corporation based in Tasmania, Australia (Gunns Limited, 2010). The company has been widely criticised for its destruction native forests and use of toxic chemicals (Putt \& Milne, 2006).

${ }^{6}$ Coking coal, also known as metallurgical coal, is coal that can be used in the production of coke which in turn is used in the blast furnace in the production of steel. Coke is used as a reductant, or reducing agent, to convert iron oxide into metallic iron which is used as input for steel production (World Coal Institute, 2009).
} 


\section{DISCUSSION AND COMMENTARY}

In this section, I examine in more detail the meaning of sustainability as articulated by Flannery and Dunphy. I then examine two major themes that arose during the interview: First, the evolution of ecologically sustainable organizations, and second, the emotionality of sustainability. I conclude with a discussion of the implications for management educators, researchers and practitioners.

\section{The meaning of sustainability}

Flannery and Dunphy describe sustainability in terms of a necessary transformation in human consciousness. Flannery cites James Lovelock’s (1979) Gaia hypothesis, which suggests that the Earth is a single interconnected ecosystem; a perspective that Flannery also draws on in his written work (e.g., Flannery, 2005, 2009). In explaining sustainability, Flannery introduces the notion of an intelligent earth, and suggests that through the evolution of human intelligence about the interconnectedness of Earth's ecosystem, humans are “poised to become the command and control system for the planet.”

Dunphy also discusses sustainability in terms of the evolution of human consciousness, but he does so from a very different perspective. Drawing on the work of Teilhard de Chardin and Freud, Dunphy discusses the current disconnection between humans and the natural environment. He suggests that what is required is an understanding that human beings are "not the masters of the Earth..." but are "part of the guardianship of its life.”

In their explanations of the meaning of sustainability Flannery and Dunphy reached a common conclusion from two very different academic perspectives. While Flannery uses the ecological perspective of Gaia to frame his understanding, Dunphy cites the more anthropocentric concept of the noösphere. Yet despite their disciplinary 
differences, both scholars arrive at the same understanding: that sustainability is the transformation of human consciousness that humans and the ecosystem are interconnected.

\section{Ecologically sustainable organizations}

In relating the concept of sustainability to the business environment, Flannery and Dunphy make the case that the evolution to sustainable organizations involves both competition and cooperation. Flannery elegantly states that "Competition is the driver of evolution but cooperation is its legacy.” Just as we see this play out in the natural world, we see it too in the business context.

Starik and Rands (1995: 909) emphasize the importance of cooperation in the evolution to ecologically sustainable organizations; defined as organizations that can exist and flourish indefinitely without negatively affecting Earth as an ecosystem. Dunphy cites examples of companies such as Westpac and Lend Lease who remain competitive within their respective industries, yet are also moving towards more cooperative modes of operating.

Flannery makes the case that government also plays an important role by providing the regulatory framework that enables corporations to be profitable while moving towards more sustainable modes of operating. Dunphy, by contrast, is critical of government policy and suggests that this type of regulatory framework is not yet realized.

Flannery and Dunphy also described the challenge for business schools, and universities more generally, in evolving into more ecologically sustainable organizations. Both professors make the case that sustainability needs to be embedded into the core business of the university. Although there is evidence that business schools are embedding sustainability into the curriculum (see for example the Aspen 
Institute’s (2010) rankings of social and environmental stewardship in business school curriculum), most are yet to embed sustainability principles into their wider operations.

\section{The emotionality of sustainability}

Growing evidence in management research has demonstrated the importance of emotions in the workplace (Ashforth \& Humphrey, 1995; Barsade, Brief, \& Spataro, 2003; Fineman, 2003; Härtel, Zerbe, \& Ashkanasy, 2005). Indeed, emotions play an important role in many management functions, including decision-making, motivation, and leadership (Ashforth \& Humphrey, 1995; Fineman, 2003). Research has also suggested that environmental issues are likely to be more emotional than other types of issues within organizations (e.g., Fineman, 1996, 1997; Pratt \& Dutton, 2000). Indeed, Flannery and Dunphy clearly demonstrate that even the most disciplined advocates cannot avoid the emotionality of sustainability.

Throughout the interview, both Flannery and Dunphy expressed strong emotions. Dunphy, for example, openly expressed his anger at organizations that knowingly avoid taking action to address environmental problems. Although Flannery initially stated that he avoids getting angry, towards the end of the interview he too expressed anger that corporations fail to take opportunities to act more sustainably.

Within the emotions literature, anger is said to result from a sense of offence or injury either to oneself, or to someone or something that is cared about (Berkowitz, 1999; Lazarus, 1991). Anger has also been found to be associated with a sense that it is still possible to respond or cope with the offence or injury (Lerner \& Tiedens, 2006). In this sense, anger may provide a stimulus or motivation to act. Indeed, my dissertation research suggests that anger is an emotional driver of sustainable behavior within organizations (Russell, 2009). 


\section{Implications}

Flannery and Dunphy articulate a vision of sustainability that issues a challenge to business schools and universities. They exhort management educators and university administrators to embed sustainability across curricula and throughout university practice. While there is evidence that curricula are changing (The Aspen Institute, 2010), as Dunphy explains, sustainability also requires modeling ecological sustainability in the way universities are run. Flannery gives examples of how universities might become ecological sustainable organizations by changing energy generation, considering sustainable transport alternatives for students, or conducting virtual classes.

It is clear from this interview that there are synergies to be gained by bringing together two leading scholars from disparate disciplinary perspectives. Yet much research in management and sustainability is limited by focusing on a single disciplinary domain (Bansal \& Gao, 2006). Starik and Rands (1995) and Gladwin, Kennelly, and Krause (1995) argue that understanding ecologically sustainable organizations is inherently complex and research in this area necessitates a multidisciplinary perspective. Taking a multidisciplinary approach, while challenging to enact, may provide management researchers with an opportunity to understand the synergies and tensions between the natural and social sciences; particularly in addressing climate change. In this way, multidisciplinary research may provide new and unique perspectives in understanding how organizations operate sustainably.

The emotionality of sustainability is another area that may be a fruitful avenue for further research. While management and sustainability scholars do mention emotionality (Andersson \& Bateman, 2000; Bansal \& Gao, 2006; Bansal \& Roth, 2000), very few have examined it directly. The interview highlighted how both 
Flannery and Dunphy felt anger in relation to the inaction of organizations in responding to environmental issues. Given that anger is an action oriented emotion (Lazarus, 1991; Lerner \& Keltner, 2001), it may have the potential to impel more sustainable behavior. Future research that explores how emotionality might become a catalyst for sustainable action would be a worthwhile avenue for future research.

A key implication for practice arises from the discussion of competition and cooperation. Starik and Rands (1995) suggested that by collaborating with organizations that are industry leaders in sustainable practices, other organizations can learn and develop more sustainable modes of operating. On this point, Dunphy cites examples of organizations achieving just this by influencing their supply chain and thereby improving the sustainability of their entire industry. Flannery submits: companies that do not collaborate and learn from industry leaders may be disadvantaged in the long-term through a failure to attract graduates and the depletion of their social and environmental capital.

\section{CONCLUSION}

My interview with Professors Flannery and Dunphy reflects the enormity of the challenge of addressing global environmental problems. Drawing on the work of Lovelock, Teilhard de Chardin, and Freud, Professors Flannery and Dunphy describe the transformation that is required in achieving a more sustainable way of living. In sharing their vision of sustainability, both professors make the case that management academics and practitioners play a vital role in achieving a sustainable future.

The major themes to arise from the interview offer a number of implications for management educators, researchers, and practitioners. In relation to management education, Flannery and Dunphy highlight the need for the sustainability agenda to be 
embedded across university curricula and operations. The major themes also provide avenues for further research. These include the need for more emphasis on multidisciplinary research, as well as the potential for emotionality to be a catalyst for sustainability action. In relation to practice, Flannery and Dunphy identified the importance of competition and cooperation in the business context; whereby collaborations with industry leaders may lead to more ecologically sustainable organizations. In this way, management scholars and practitioners play a vital role in assisting the transformation required in achieving a sustainable future.

\section{ACKNOWLEDGEMENTS}

Thanks must go foremost to Tim Flannery and Dexter Dunphy for taking time to speak with me and for sharing their knowledge and valuable insights. I am also grateful to the ANZAM executive for arranging the interview. Thank you also to Neal Ashkanasy from The University of Queensland and to my colleagues from the Griffith Business School who provided valuable feedback on earlier versions of this manuscript.

\section{REFERENCES AND SELECTED PUBLICATIONS}

Andersson, LM and Bateman, TS (2000) Individual environmental initiative: Championing natural environmental issues in U.S. business organizations, Academy of Management Journal 43(4): 548-570.

Ashforth, BE and Humphrey, RH (1995) Emotion in the workplace: A reappraisal, Human Relations 48(2): 97-125. 
Bansal, P and Gao, J (2006) Building the future by looking to the past: Examining research published on organizations and environment, Organization \& Environment 19(4): 458-478.

Bansal, P and Roth, K (2000) Why companies go green: A model of ecological responsiveness, Academy of Management Journal 43(4): 717-736.

Barsade, SG,Brief, AP and Spataro, SE (2003) The affective revolution in organizational behavior: The emergence of a paradigm, in Greenberg J (Ed), Organizational behavior: State of the science pp 3-50, Lawrence Erlbaum, Mahwah, NJ.

Benn, S and Dunphy, D (Eds) (2007) Corporate governance and sustainability: Challenges for theory and practice, Routledge, London.

Benn, S, Dunphy, D and Griffiths, AB (2006) Enabling change for corporate sustainability: An integrated perspective, Australasian Journal of Environmental Management 13(3): 156-166.

Benn, S, Dunphy, DC and Griffiths, A (2004) Corporate change for sustainability: The way ahead, Australian Conservation Foundation, Carlton, VIC.

Berkowitz, L (1999) Anger, in Dalgleish T \& Power MJ (Eds) Handbook of cognition and emotion, pp 411-428, John Wiley \& Sons, Chichester.

Collins, DA, Della-Marta, PM, Plummer, N and Trewin, BC (2000) Trends in annual frequencies of extreme temperature events in Australia, Australian Meteorological Magazine 49: 277-292.

Dunphy, D (2003) Corporate sustainability: Challenge to managerial orthodoxies, Journal of the Australian and New Zealand Academy of Management 9(1): 211. 
Dunphy, D, Benveniste, J, Griffiths, A and Sutton, P (Eds) (2000) Sustainability: The corporate challenge of the 21st century, Allen \& Unwin, St Leonards, NSW.

Dunphy, D, Griffiths, A and Benn, S (2007) Organizational change for corporate sustainability: A guide for leaders and change agents of the future, Routledge, London.

Dunphy, DC and Griffiths, A (2006) The sustainable corporation: Organisational renewal in Australia, Allen \& Unwin, St Leonards, NSW.

Fineman, S (1996) Emotional subtexts in corporate greening, Organization Studies 17(3): 479-500.

Fineman, S (1997) Constructing the green manager, British Journal of Management 8(1): 31-38.

Fineman, S (2003) Understanding emotion at work, Sage, London.

Flannery, TF (2005) The weather makers: The history \& future impact of climate change, Text Publishing, Melbourne, VIC.

Flannery, TF (2009) Now or never: A sustainable future for Australia?, Black Inc, Melbourne.

Flannery, TF (1995) The future eaters: An ecological history of the Australian lands and people, Reed Books, Sydney.

Flannery, TF (1997) Achieving ecological sustainability, Australasian Science 18(4): 8-9.

Flannery, TF (1999) Debating extinction, Science 283(5399): 182-183.

Flannery, TF (2001a) The eternal frontier: An ecological history of North America and its peoples, Text Publishing, Melbourne.

Flannery, TF (2001b) North American devastation or global cataclysm? (Perspectives: Geology) (Brief Article), Science 294(5547): 1668-1669. 
Gladwin, TN, Kennelly, JJ and Krause, T-S (1995) Shifting paradigms for sustainable development: Implications for management theory and research, Academy of Management Review 20(4): 874.

Gore, A (Writer) (2006) An inconvenient truth, in Bender, L, Burns SZ \& David, L (Producers), United International Pictures (UIP), USA.

Gunns Limited (2010) Gunns: About Us Retrieved 5 January, 2010, from http://www.gunns.com.au/about-us/.

Härtel, CEJ, Zerbe, WJ and Ashkanasy, NM (2005) Emotions in organizational behavior, Lawrence Erlbaum Associates, Mahwah, NJ.

Lazarus, RS (1991) Emotion and adaptation, Oxford University Press, New York.

Lerner, JS and Keltner, D (2001) Fear, anger, and risk, Journal of Personality and Social Psychology 18(1): 146-159.

Lerner, JS and Tiedens, LZ (2006) Portrait of the angry decision maker: How appraisal tendencies shape anger's influence on cognition, Journal of Behavioral Decision Making 19(2): 115-137.

Lovelock, JE (1979) Gaia: A new look at life on earth, Oxford University Press, Oxford.

Pittock, B (Ed) (2003) Climate change: An Australian guide to the science and potential impacts, Australian Greenhouse Office, Canberra, ACT.

Plummer, N, Salinger, MJ, Nicholls, N, Suppiah, R, Hennessy, KJ, Leighton, RM, et al. (1999) Changes in climate extremes over the Australian region and New Zealand during the Twentieth Century Climatic Change 42(1): 183-202.

Pratt, MG and Dutton, JE (2000) Owning up or opting out: The role of emotions and identities in issue ownership, in N. M. Ashkanasy, C. E. J. Härtel \& W. J. 
Zerbe (Eds.) Emotions in the workplace: Research, theory, and practice (pp. 103-129), Quorum Books, Westport.

Putt, P and Milne, C (2006) Don't pulp our future: A joint submission to the resource planning and development commission on Gunns' pulp mill proposal, The Greens Tasmania, Hobart, TAS.

Russell, S (2009) Proenvironmental behaviour in organisations: The role of emotion and issue ownership, Unpublished PhD Thesis, The University of Queensland, St Lucia.

Samson, PR and Pitt, D (Eds.) (1999) The biosphere and noosphere reader: Global environment, society and change, Routledge, London.

Shrivastava, P (1995) The role of corporations in achieving ecological sustainability, Academy of Management Review 20(4): 936-960.

Starik, M and Marcus, AA (2000) Introduction to the special research forum on the management of organizations in the natural environment: A field emerging from multiple paths, with many challenges ahead, Academy of Management Journal 43(4): 539.

Starik, M and Rands, GP (1995) Weaving an integrated web: Multilevel and multisystem perspectives of ecologically sustainable organizations, Academy of Management Review 20(4): 908-935.

The Aspen Institute (2010) Rankings: Global 100 Retrieved 5 January 2010, from http://www.beyondgreypinstripes.org/rankings/index.cfm.

World Coal Institute (2009) Coal \& Steel Report. World Coal Institute, London. WWF (2010) Earth Hour Retrieved 5 January 2010, from http://www.earthhour.org/Homepage.aspx. 


\begin{abstract}
AUTHOR BIOGRAPHY
Sally V. Russell is a lecturer in sustainable enterprise and organizational behavior at the Griffith Business School, Griffith University. Sally was awarded her doctorate from The University of Queensland in 2009, for which she received the ANZAM Best Doctoral Dissertation Award. Her research explores the drivers of sustainable behavior, particularly examining the role of emotion as a driver of proenvironmental behavior.
\end{abstract}

